\title{
Techno-economic analysis for the role of single end energy user in mitigating GHG emission
}

\author{
Waqas Ahmed ${ }^{1}$, Jamil Ahmed Sheikh², Muhammad Nouman ${ }^{3}$, Mian Farhan Ullah ${ }^{4}$ and \\ M. A. Parvez Mahmud ${ }^{3 *}$ (1)
}

\begin{abstract}
Background: Households, as end energy users, consume grid electricity to meet their energy demands. However, grids across the globe for energy production are majorly based on fossil fuel technology and make the highest contributions to global warming and climate change due to greenhouse gases (GHG) emissions. This generic study aims to investigate the minute role of a single-end energy consumer in GHG mitigation by switching to a rooftop PV system to meet his energy demands and trading surplus energy to the grid through its techno-economic analysis.
\end{abstract}

Method: For the study impact, NASA Meteorological Data are used to select an ideal single energy user equipped with a 10-kW PV system based on annual average daily solar radiation and ambient temperature through MATLAB/ Simulink, for 11 populous cities in Pakistan. Helioscope software is used to select tilt and azimuthal angles to maximize the solar radiation intercept. Afterward, RETScreen software is used for cost, financial and GHG analysis.

Result and conclusion: A single end energy user equipped with a 10-kW PV system switched to a green energy source from a fossil fuel-based grid has the potential to avoid the burning of $3570.6 \mathrm{~L}$ of gasoline by producing $16,832 \mathrm{kWh}$ of green energy per annum, while financially recovering the 10-kW PV system's $7337 \$$ grid-tied investment in 5 years (equity) and in 9 years (equity) in a $9077 \$$ stand-alone system over its 25 -year life. This approach provides relief to end energy users from high priced grid electricity through environmental friendliness by mitigating 8.3 tons of $\mathrm{CO} 2$ equivalent emissions per annum from energy production, while providing relief to the main grid by grid stabilization through peak shaving, in the broad sense.

Keywords: Photovoltaic (PV) system, GHG emission, Feasibility assessment, Economic analysis

\section{Introduction}

Energy serves as the backbone of the modern era, while developing countries face severe energy shortages [1]. On the contrary, across the globe, there is another movement with growing concern over energy production through conventional energy resources in the context of global climate change [2]. In Pakistan, a major energy share is from conventional energy resources [3, 4]. Moreover, research

\footnotetext{
*Correspondence: m.a.mahmud@deakin.edu.au

${ }^{3}$ School of Engineering, Deakin University, Geelong, VIC 3216, Australia

Full list of author information is available at the end of the article
}

analysis suggests an increment of $2.9 \%$ and 2.0 in energy consumption and carbon emissions, respectively, in 2018 [5]. Conventional energy production involves emissions of nitrous oxide $\left(\mathrm{N}_{2} \mathrm{O}\right)$, methane $\left(\mathrm{CH}_{4}\right)$, and water vapors $\left(\mathrm{H}_{2} \mathrm{O}\right)$ apart from carbon dioxide $\left(\mathrm{CO}_{2}\right)$ emissions. These greenhouse gases (GHG) block the re-emitted radiation from the Earth initially received by the Sun, hence raising the Earth's temperature, the cause of climate change $[6,7]$. In response, the world is implementing solutions to reduce this cause without any change in demand and supply, i.e., the electric grid transformation from conventional energy resources to green renewable energy original author(s) and the source, provide a link to the Creative Commons licence, and indicate if changes were made. The images or other third party material in this article are included in the article's Creative Commons licence, unless indicated otherwise in a credit line to the material. If material is not included in the article's Creative Commons licence and your intended use is not permitted by statutory regulation or exceeds the permitted use, you will need to obtain permission directly from the copyright holder. To view a copy of this licence, visit http://creativecommons.org/licenses/by/4.0/. The Creative Commons Public Domain Dedication waiver (http://creativeco mmons.org/publicdomain/zero/1.0/) applies to the data made available in this article, unless otherwise stated in a credit line to the data. 
resources has moved due to environmental concerns [8]. The Paris Climate Accord [9], Kyoto protocol [10] and European Union targets-2020, 2030 and 2050 [11-13] as its important conventions and energy/emission targets.

In South Asia, the developing country Pakistan has faced energy shortages since its birth, and in 2017 from 5 to 7 gigawatts [14]. Pakistan's energy sector is still burdened with circular debts [15]. The world is moving to green energy resources while Pakistan's major share of energy is from conventional energy resources $[3,4]$ and these conventional energy resources, which involve GHG emissions and climatic concerns, are discussed in the literature as energy analysis with their role in $\mathrm{CO} 2$ emissions [16]. However, Pakistan's unique geographical coordinates and seasonal pattern variations are ideal for green renewable energy production, such as solar PVs and wind power plants. Pakistan's mean solar irradiation is $5-7 \mathrm{kWh} / \mathrm{m} 2 /$ day, and on average, the sun shines for $8-10 \mathrm{~h} /$ day for over and above 300 days in a year [17, 18]. According to a careful estimation by the Alternative Energy Development Board (AEDB), Pakistan has a 2900 GW solar potential [19]. This offers Pakistan a tremendous possible solution to address its energy issues by using green renewable energy resources promptly to address its two major challenges at the same time. Conventional energy resources are not only expensive, but fluctuations in oil prices burden the country's imports. With the increase in the population, energy consumption has experienced an increase in the household share of $35-46.5 \%$ in the last two decades [3, 20]. An increase in energy demand forecast is estimated at [21]. Across the globe, developing countries and developed countries have initiated incentives-based support programs for faster penetration of green renewable energy sources such as distributed solar photovoltaic (PV) generation. Moreover, net-metering has been successfully implemented by Denmark, Belgium, Australia, the USA, China, Brazil, Bangladesh, India, etc., for the rapid market expansion of solar PVs [20]. In Pakistan, grid-tied residential PV generation systems installations are very slow, despite higher solar irradiation, the enactment of net-metering by the government [22], and a significant decrease in solar PV module prices [20]. Moreover, green renewable-based energy generation such as PV systems will help to reduce GHG emissions as well.

The quantity of electricity produced at any location depends on the extent of solar irradiation at the location [7]. However, the output of the PV module linearly depends on ambient temperature; an increase in ambient temperature causes efficiency loss, hence a decrease in PV output [23]. Literature suggests that grid-connected solar PV systems are more feasible, reliable, and economical than stand-alone systems [24]. And for the deployment of solar power plants, there is a need for techno-economic and environmental feasibility analysis before making investment decisions [25]. For this purpose, a relatively easy and user-friendly software package to analyze various types of renewable energy and energy-efficient technologies inculcating PV systems, RETScreen, is used. It was developed by Canada for multiple analyses such as energy, feasibility, emissions, financial, and risk assessment [26]. In literature, multiple studies are considered in RETScreen which provide valuable information on environmental assessment, emission assessment, feasibility assessment, technical assessment, and economic assessment comprising cost and financial assessments of mega projects in multiple countries across the globe. Nigeria's $100 \mathrm{MW}$ proposed PV system is assessed in the country's 25 locations for financial (profit) assessment and its relative GHG emissions mitigation effectiveness [7], Bangladesh's $1 \mathrm{MW}$ grid-connected PV system's financial viability in 14 regions of the country [27], Chile's 30-MW PV plant's financial/sensitivity assessment at 22 locations in the country [28] Iran's 100-kW grid-tied PV system for economic assessment [29] and Pakistan's 10-MW PV system for economic viability at eight sites in the country [3]. Literature provides an assessment of multiple regions of land-based on RETScreen.

The modern era is based on energy, while its production technologies involve GHG emissions. Therefore, the PV system in terms of energy production, green nature and tremendous potential across the globe is widely utilized. However, low-capacity rooftop-mounted PV systems at end energy users can meet their energy demand by shifting to green renewable energy sources and transmitting surplus energy of the day to the fossil fuel-based main grid. This approach avoids the burning of fossil fuels which was required to meet the end user's energy demand, hence, mitigating GHGs at the main grid-level through a PV-equipped single energy user. This generic study aims to highlight the role and importance of a single end energy user in meeting his energy demand and mitigating GHG emissions using a PV system through its techno-economic analysis. For study impact, a 10-kW PV system is considered after the careful selection of the best location among 11 densely populated cities in Pakistan through Simulink based on daily solar radiation and ambient temperature, data retrieved from the National Aeronautics and Space Administration (NASA) Meteorological Data. Helioscope software is utilized for the optimal orientation (tilt and azimuth) angle selection for the fixed PV system to maximize the energy yield. Finally, RETScreen Expert software is utilized to analyze the degree of relief from high electricity pricing received by end energy users in the project's 25 life-year spans. For this purpose, cost analysis and financial analysis were 
carried out with GHG mitigation potential of the $10-\mathrm{kW}$ PV system at the end energy user, individual level. The proposed system is reflected in the form of the flow diagram in Fig. 1.

\section{Literature analysis and proposed system novelty}

The PV system is a preferred energy source, used across the globe because of its green, renewable nature and tremendous potential [30]. Therefore, in the literature, PV system potential is extensively analyzed in multiple world regions through financial, sensitivity, risk, GHG, etc., analyses, [3, 7, 27-29, 31-33]. However, literature extensively discusses the prominent role of PV systems in megawatt-scale projects, but the minute capacity with the prominent role of a single end energy user, which is fed from the fossil fuel-based national grid, switched to a green PV system capable of mitigating GHG emissions, is majorly overlooked [30]. Moreover, in literature, the optimal location for the installation of a PV system plant is either decided by a single parameter; average daily solar radiation [3], or after a detailed analysis of each location [7]. The prominent role of ambient temperature in the operation of PV systems [23] is overlooked in location selection, which highly affects the PV system's efficiency, performance, and output.

In addition, the selection of orientation (tilt and azimuth) angles is either assumed to be a fixed value [31] or the PV system tilt angle is adjusted to the respective location's latitude $[3,30]$, which is also suggested by the PVGIS tool [30]. However, the selection of the orientation angle of a no-tracking fixed PV system to any fixed value or location's latitude may limit the PV system's potential, therefore it needs careful and accurate estimation [30]. This study considers the grid-tied small-capacity PV system-equipped end energy user an important role in GHG emissions mitigation analysis by selecting the optimal location of a 10-kW end energy user PV system among 11 populous cities in Pakistan using two main respective geographical parameters; annual average daily solar radiation potential and annual average ambient temperature with PV system output in MATLAB/Simulink software for detailed analysis. Moreover, the end energy user's PV system orientation angles are adjusted to optimal tilted and azimuth angles to maximize the annual average daily solar radiation intercept potential using Helioscope software, because of the PV system's

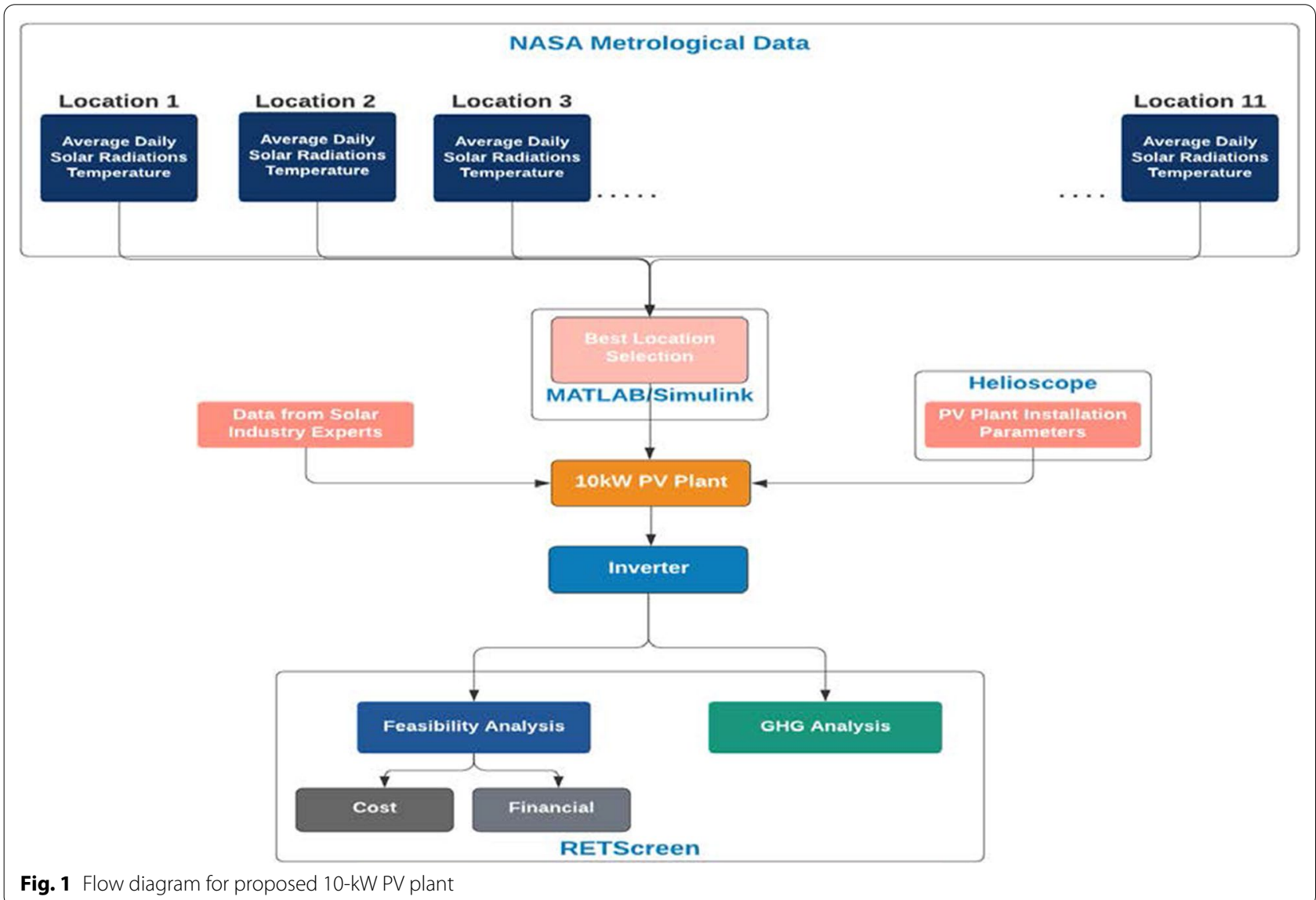


fixed orientation. Finally, investment, financial, and GHG analyses are carried out on RETScreen Expert Software to attract end energy users due to its economic perspective. The PV system's detailed analysis among related literature with the proposed system is presented in Table 1.

\section{Methodology}

A small part of the energy paradigm is necessary to assess the PV system feasibility and emissions end energy users. The end energy user consumes the energy, but trades surplus energy with the main grid in the case of a PV systemequipped home. This approach relaxes the national grid in peak shaving and stabilization and lessens the dependence on conventional sources. It also highlights the end energy user's small but significant role in environmental concerns. However, rooftop PV systems with battery storage systems provide a higher degree of independence from the main grid but have very weak or no investment return even with government subsidies, regardless of storage unit size and influencing parameters [34]. Therefore, the proposed PV system is an on-grid system, which means no backup battery system is involved. PV systems running costs as well as stack emissions $\left(\mathrm{CO}_{2}, \mathrm{H}_{2} \mathrm{O}\right.$, etc.) are zero.

\section{Location selection}

The 11 geographical sites are Peshawar, Multi Gardens (Wah), Multan, Lahore, Rawalpindi, Sargodha, Faisalabad, Bahawalpur, Bannu, D.I. Khan, and Jhang. Geographical data are provided by RETScreen Expert, provided in Table 2. RETScreen Expert utilizes meteorological data for any specific location from its meteorological data inventory provided by NASA [26]. MATLAB/ Simulink is used for best location selection of energy users based on two important parameters, affecting the output most; daily solar radiation and ambient air temperature $[7,23]$ Simulink PV module parameters to verify the maximum possible power at each of 11 locations through daily solar radiation and ambient temperature are provided in Table 3. A DC load is connected at PV output for the measurement of possible power output. A ramp load starts from 0 to 21.1.

Careful analysis of results favors Multi Gardens with Wah Climatic Data with $242 \mathrm{~W}$ production in the presence of $5.19 \mathrm{kWh} / \mathrm{m} 2$ annual average daily solar radiation with a 22.8 Celsius air ambient temperature. Rawalpindi, results showed that its power output was the lowest among all, 206 Watts in the presence of an annual average of $4.02 \mathrm{kWh} / \mathrm{m} 2$ daily solar radiation with a $21.6 \mathrm{Cel}-$ sius air ambient temperature. Based on Simulink results, the Multi Gardens location is best for detailed analysis of a 10-kW PV system for a single end energy user role in GHG mitigation.

\section{Parameters selection}

NASA's complete meteorological data for the proposed $10-\mathrm{kW}$ PV system at Multi Gardens are provided in Table 4. It provides valuable monthly average data for multiple key factors, like daily solar radiation-horizontal, air and Earth temperature, relative humidity, wind speed, and atmospheric pressure over a whole year. Figure 2 reflects monthly average daily solar radiation-horizontal surface values and average ambient air temperature factors for a whole year, respectively. These two factors play pivotal roles in PV system output [35].

For a realistic assessment of the proposed 10-kW PV system at Multi Gardens, RETScreen must be provided with real project values, and these values were provided by technical workers working in the same energy domain. The Multi Gardens location has considerable dust pollution due to its proximity to crushing machines, significantly affecting PV system output. A value of $12 \%$ was chosen for PV array losses as miscellaneous losses. Since azimuthal and tilt angle ensure the maximum energy extraction from solar radiation, Helioscope, advanced solar design software, is utilized. Solar companies use the Helioscope to design, engineer, and sell solar arrays [36]. Since the grid operates on a $50-\mathrm{Hz}$ alternating current, an inverter is required to invert $\mathrm{DC}$ to $\mathrm{AC}$, which has losses involved in it as well. A modern, efficient inverter is considered with $98 \%$ efficiency. Plant data, PV system electrical specifications, and main inverter data are provided in Tables 5, 6, and 7.

\section{Result analyses Cost analysis}

Capital cost analysis is required for the user in order to match it with his purchasing power. This cost analysis provides an initial detailed investment plan for the proposed 10-kW system at the best location, Multi Gardens. Cost analysis provides a complete knowledge of the investment divided into the feasibility study, engineering cost, PV system cost, inverter costs, and miscellaneous costs, which are $93 \$, 360 \$, 4924 \$$, and $1959 \$$, respectively. Table 8 provides data for a proposed $10-\mathrm{kW}$ PV system aftermarket survey of the PV system and from the same field experts. RETScreen offers the right place to carry out either a detailed or short-cost analysis. RETScreen detail analysis is used for this cost study.

The feasibility study gives insights about site investigation, resource assessment, environmental assessment, detailed cost estimate, and report preparation. It also provides engineering studies about mechanical design, electrical design, and civil structural support design. These are soft studies. On the contrary, the power system study asks for input regarding photovoltaic- $10 \mathrm{~kW}$ cost and its distribution box for net-metering. Finally, inverter and 


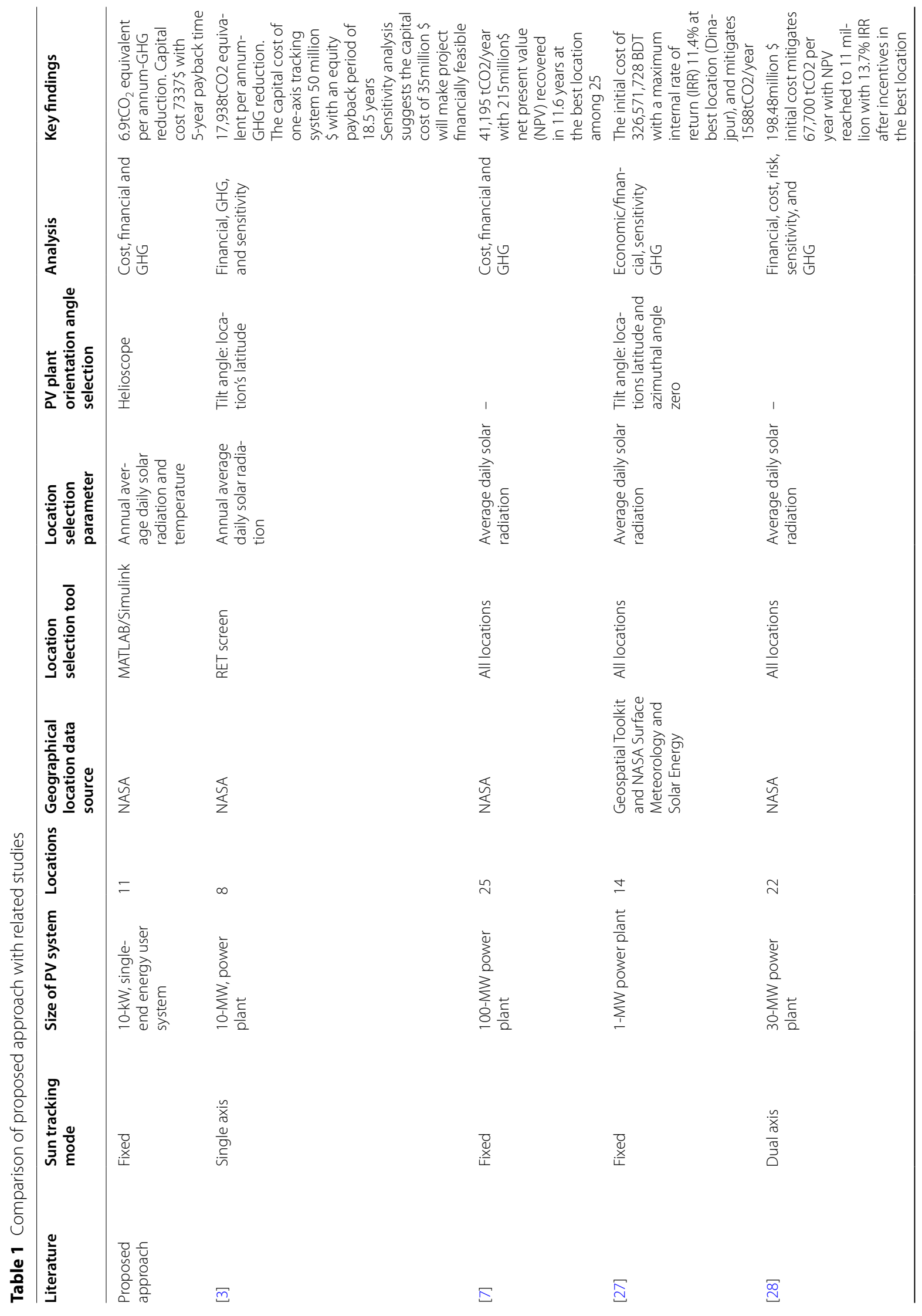




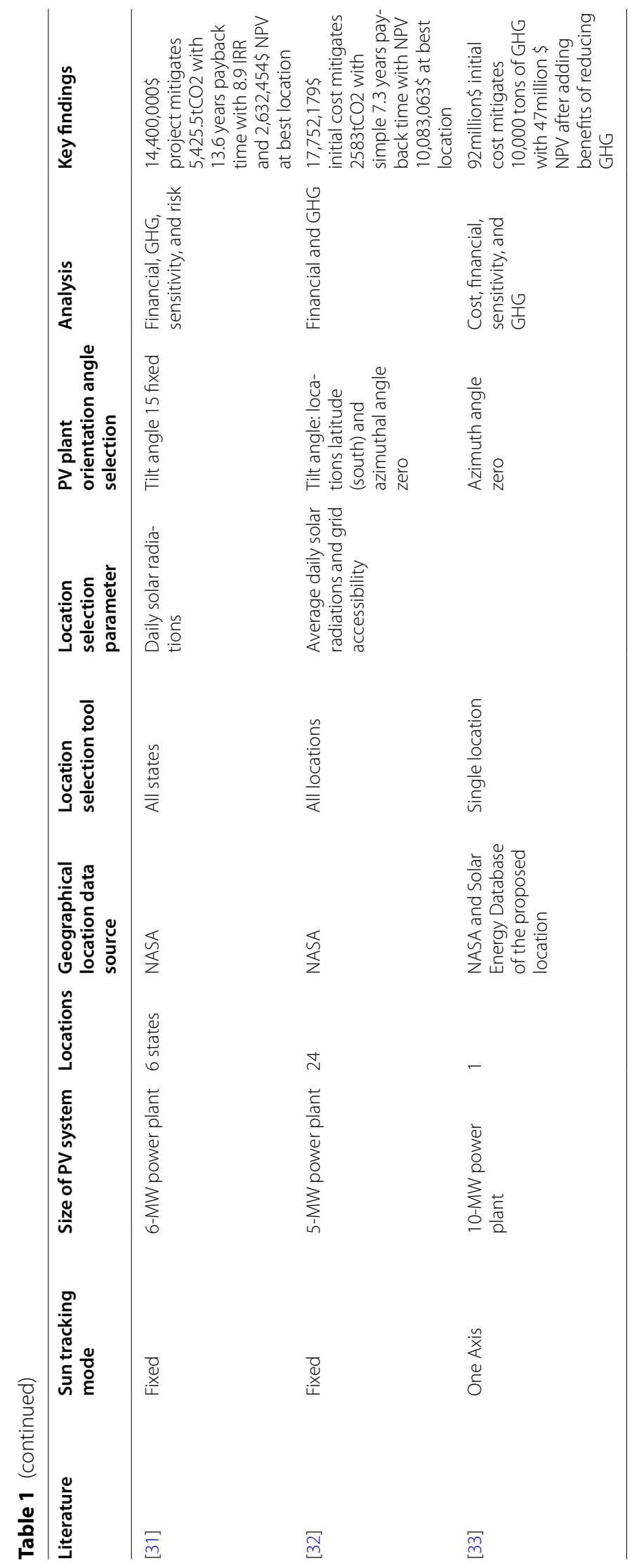


Table 2 Average daily solar radiation and ambient temperature of 11 Pakistan's geographical locations

\begin{tabular}{|c|c|c|c|c|c|c|}
\hline Location & $\begin{array}{l}\text { Ambient } \\
\text { temperature } \\
\text { (Celsius) }\end{array}$ & $\begin{array}{l}\text { Daily solar radiation e } \\
\text { horizontal }\left(\mathrm{kWh} / \mathrm{m}^{2} / \text { day }\right)\end{array}$ & Latitude & Longitude & $\begin{array}{l}\text { Elevation } \\
\text { (meters) }\end{array}$ & $\begin{array}{l}\text { Power } \\
\text { output } \\
\text { (Watt) }\end{array}$ \\
\hline Peshawar & 22.7 & 5.16 & 334 & 71.5 & 345 & 241 \\
\hline Multi Gardens (Wah) & 22.8 & 5.19 & 33.8 & 72.8 & 502 & 242 \\
\hline Multan & 25.3 & 5.09 & 30.2 & 71.5 & 125 & 236 \\
\hline Lahore & 24.4 & 4.68 & 31.6 & 74.3 & 220 & 225 \\
\hline Rawalpindi & 21.6 & 4.02 & 33.6 & 73 & 508 & 206 \\
\hline Sargodha & 25.6 & 5.10 & 32.1 & 72.7 & 274 & 236 \\
\hline Faisalabad & 26.6 & 5.03 & 31.4 & 73.1 & 18 & 232 \\
\hline Bahawalpur & 27.9 & 5.13 & 29.4 & 71.7 & 117 & 234.5 \\
\hline Bannu & 23.7 & 4.97 & 33 & 70.6 & 542 & 234 \\
\hline D.I. Khan & 26.1 & 4.86 & 31.8 & 70.9 & 255 & 228 \\
\hline Jhang & 26.8 & 5.02 & 31.3 & 72.3 & 160 & 231.5 \\
\hline
\end{tabular}

Table 3 Simulink PV module parameters for location selection

\begin{tabular}{ll}
\hline Parameters & Values \\
\hline Max power & $59.85 \mathrm{~W}$ \\
Open-circuit voltage & $21.1 \mathrm{~V}$ \\
Short-circuit current & $3.8 \mathrm{~A}$ \\
Voltage at maximum power point (Vmp) & $17.1 \mathrm{~V}$ \\
Current at maximum power point (Imp) & $3.5 \mathrm{~A}$ \\
Temperature coefficient of Voc (\%deg C) & -0.38 \\
Temperature coefficient of Isc (\%deg C) & 0.065 \\
\hline
\end{tabular}

miscellaneous analysis are about inverter cost, installation cost, training, and commissioning. These are broadly referred to as hardware studies [37]. Table 8 shows PV system and inverter costs account for more than $85 \%$ of the $10-\mathrm{kW}$ proposed system's capital cost at a specified location.

\section{Financial analysis}

Financial analysis involves costs like capital cost, electricity export rate, electricity export escalation rate, inflation rate, project life, debt ratio, etc. RETScreen on these inputs generates a detailed financial analysis sheet for interested end energy users. The government of Pakistan offers income tax and premium tariff exemptions to support renewable projects [38], so the proposed PV system's financial study includes no income tax and premium tariff. The electricity escalation rate is considered at $6 \%$ per annum. RETScreen suggests a debt ratio range,

Table 4 The climate data of Multi Gardens, Pakistan

\begin{tabular}{|c|c|c|c|c|c|c|}
\hline Month & $\begin{array}{l}\text { Daily solar radiation- } \\
\text { horizontal (kWh/m²/day) }\end{array}$ & $\begin{array}{l}\text { Ambient } \\
\text { temperature } \\
\text { (Celsius) }\end{array}$ & $\begin{array}{l}\text { Earth temperature } \\
\text { (Celsius) }\end{array}$ & $\begin{array}{l}\text { Relative } \\
\text { humidity }\end{array}$ & $\begin{array}{l}\text { Wind speed } \\
(\mathrm{m} / \mathrm{s})\end{array}$ & $\begin{array}{l}\text { Atmospheric } \\
\text { pressure (kPa) }\end{array}$ \\
\hline January & 3.19 & 10.5 & 8.4 & 45.1 & 2.0 & 95.0 \\
\hline February & 3.92 & 12.5 & 11.2 & 49.0 & 2.2 & 94.8 \\
\hline March & 4.87 & 17.8 & 17.0 & 46.0 & 2.3 & 94.6 \\
\hline April & 6.22 & 23.8 & 23.6 & 38.7 & 2.4 & 94.3 \\
\hline May & 7.16 & 30.3 & 31.0 & 25.5 & 2.4 & 93.8 \\
\hline June & 7.43 & 34.2 & 35.7 & 25.0 & 2.3 & 93.4 \\
\hline July & 6.48 & 32.5 & 34.1 & 46.7 & 2.3 & 93.3 \\
\hline August & 5.75 & 30.2 & 31.2 & 57.4 & 2.2 & 93.6 \\
\hline September & 5.51 & 27.9 & 28.0 & 48.1 & 1.9 & 94.0 \\
\hline October & 4.93 & 23.1 & 21.8 & 33.9 & 2.0 & 94.5 \\
\hline November & 3.84 & 17.5 & 15.3 & 30.9 & 2.0 & 94.9 \\
\hline December & 2.97 & 12.8 & 10.2 & 37.3 & 1.9 & 95.0 \\
\hline Annual & 5.19 & 22.8 & 22.3 & 40.3 & 2.1 & 94.3 \\
\hline
\end{tabular}




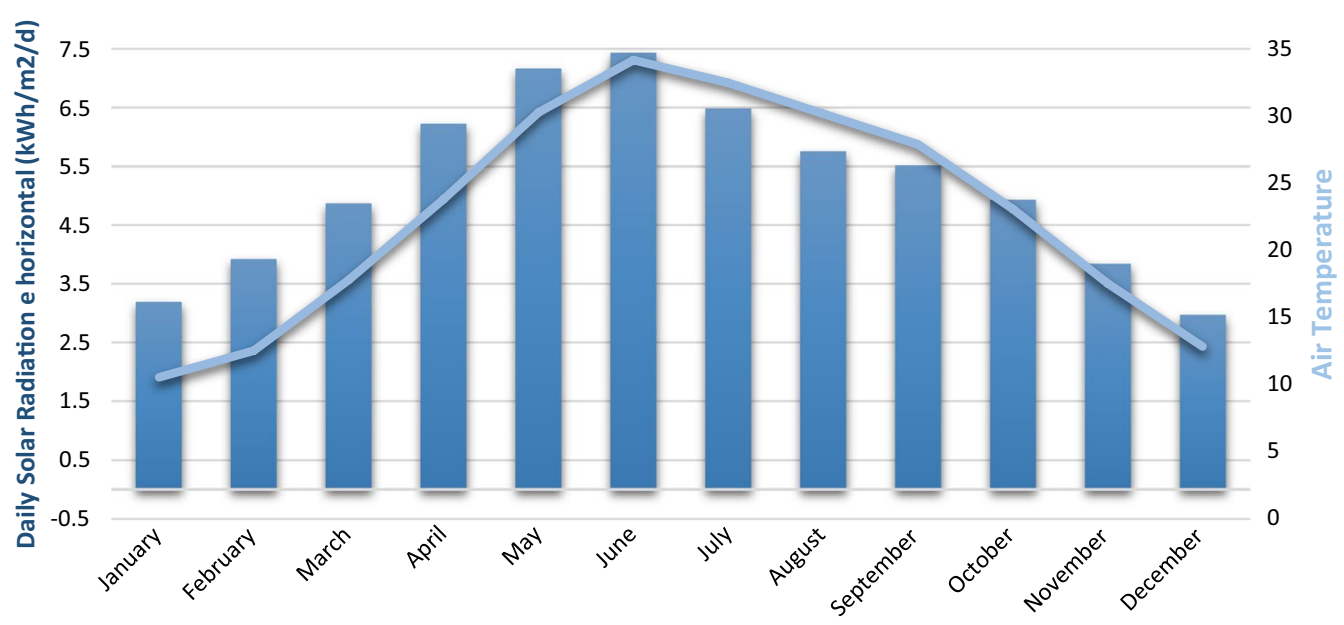

Fig. 2 Daily solar radiation and ambient temperature over a whole year at Multi Gardens

Table $\mathbf{5}$ Technical specifications of on-grid photovoltaic system

\begin{tabular}{ll}
\hline Plant capacity & $\mathbf{1 0 ~ k W}$ \\
\hline Tracking mode & Fixed \\
Tilt angle & $-18.4[36]$ \\
Miscellaneous PV array losses & $12 \%$ \\
Azimuth & $180[36]$ \\
\hline
\end{tabular}

Table 6 Electrical data of PV module

\begin{tabular}{lc}
\hline Power (nominal) & $\mathbf{3 3 5} \mathbf{~ W}$ \\
\hline Efficiency & $19.9 \%$ \\
Open-circuit voltage & $44.8 \mathrm{~V}$ \\
Short-circuit current & $9.51 \mathrm{~A}$ \\
Power temperature coefficient & $-0.37 \% / C e l s i u s$ \\
\hline
\end{tabular}

Table 7 Inverter specifications

\begin{tabular}{ll}
\hline MPPT tracker & Enabled \\
\hline AC nominal output & $10,000 \mathrm{~W}$ \\
Frequency & $50 \mathrm{~Hz}$ \\
Max. efficiency & $98.0 \%$ \\
\hline
\end{tabular}

Table 8 Percentage distribution of capital cost for proposed $10 \mathrm{~kW}$

\begin{tabular}{|c|c|c|}
\hline \multirow[t]{5}{*}{ Initial cost } & Feasibility study & $1.3 \%$ \\
\hline & Engineering & $4.9 \%$ \\
\hline & Power system & $67.1 \%$ \\
\hline & Inverter and miscellaneous & $26.7 \%$ \\
\hline & Total & $100 \%$ \\
\hline
\end{tabular}

Table 9 Financial inputs for proposed 10-kW PV plant

\begin{tabular}{ll}
\hline Project life & 25 \\
Inflation & 9.1 \\
Electricity export rate & $0.1 \$ / \mathrm{kWh}$ \\
Electricity export escalation & $6 \%$ \\
Discount rate & $9 \%$ \\
Debt ratio & $50 \%$ \\
Debt term & 7 \\
\hline
\end{tabular}

but a $50 \%$ debt ratio was utilized for financial analysis for a proposed 10-kW PV system project. Some values assumed by RETscreen were taken as is.

The discount rate suggested by RETScreen for North American projects was used to select the discount rate for this project, and 9\% was appropriate. Table 9 provides input value for the financial assessment of the proposed project. Operation and maintenance costs are considered low due to no moving parts in the system. However, dealing with dust at the proposed project location is important to keep its efficiency at an acceptable value. O\&M cost for a fixed PV system was estimated at 460 \$ per year. O\&M costs majorly cover the repair and replacement costs of the inverter after its 10 years of useful life. These values and the rest of the values were carefully chosen after communication with workers in relevant fields.

The project's total cost is $7337 \$$, excluding O\&M costs. Electricity exported to the grid was $16,832 \mathrm{kWh}$, which earned $1683 \$$ at the electricity export rate of $0.1 \$ / \mathrm{kWh}$. The project's annual income/cost and cumulative cash flows are illustrated in Fig. 3a, b, respectively. This project is financially good as the initial cost is recovered in about five years (equity) and the investor/end energy users start earning in the following years. 


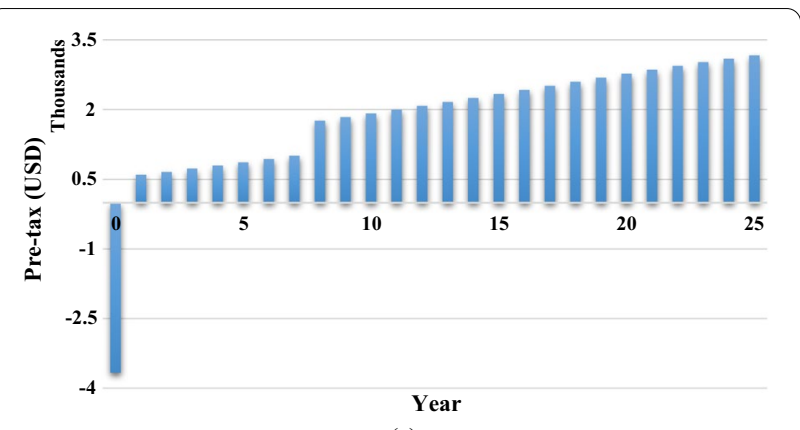

(a)

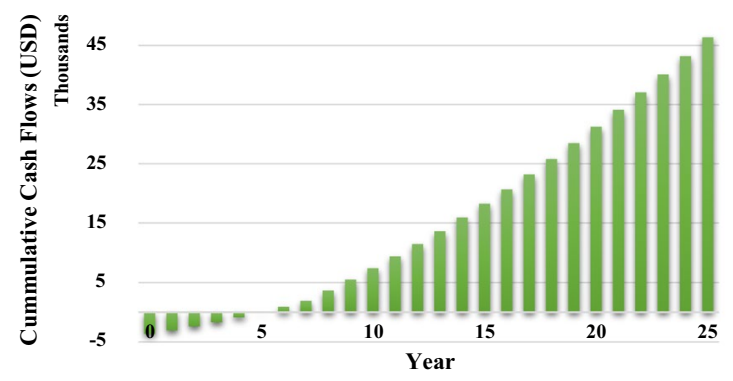

(b)

Fig. 3 Proposed 10-kW system. a Annual income/cost. b Cumulative cash flows

RETscreen expert based on inputs calculates $681 \$$ first year debt payments and simple payback of 6 years and equity payback of 5 years.

\section{Emission analysis}

The RETScreen expert provides emission analysis for green renewable energy resources and their equivalent GHG emission mitigation potential. Since several gases $\left(\mathrm{CO}_{2}, \mathrm{H}_{2} \mathrm{O}, \mathrm{NO}_{\mathrm{x}}\right.$, etc. $)$ are released while burning, the RETScreen expert provides an equivalent annual amount of $\mathrm{CO} 2$ to total emissions. It is processed by translating emission gases into $\mathrm{CO}_{2}$ based on their global warming potential [6]. This proposed system is effective since it is equivalent to 1.5 cars and light trucks not used, 3,570.6 L of gasoline not consumed, 19.3 barrels of crude oil not consumed, 8.3 people reducing energy use by $20 \%, 1.9$ acres of forest absorbing carbon, 0.8 hectares of forest absorbing carbon that could be emitted in the case of conventional energy plants, and finally, it is equivalent to 2.9 tons of waste recycled. It is important to mention that this data varies from location to location even if a $10-\mathrm{kW}$ PV system with the same specifications is considered, as elaborated in Tables 5, 6, and 7, because daily solar radiation and ambient air temperature vary from location to location. The RETScreen expert suggests the annual GHG emissions reduction due to the 10-kW PV system at the specified location of Multi Gardens is equivalent to roughly 8.3 tons of $\mathrm{CO} 2$ per year with equivalent annual electricity exported to the grid of $16,832 \mathrm{kWh}$. Transmission and distribution [T\&D] losses were considered 17.136\% in Pakistan [39], while T\&D losses for the specified project were zero since it was a rooftop-mounted PV system and local energy consumption.

\section{GHG mitigation effectiveness in Pakistan's scenario}

In Pakistan's three provinces, Sindh [40], Punjab [41], and Baluchistan [42], literature suggests that $4 \mathrm{kWh}$ of energy can be produced per liter from a $20-\mathrm{kW}$ diesel generator. For the proposed PV system, 16,832 kWh per annum of energy is produced through solar radiation in Multi Gardens, which is equivalent to the consumption of $4208 \mathrm{~L}$ of oil or saving the same amount of oil. For the sake of simplicity, this project in its lifetime will avoid burning $105,200 \mathrm{~L}$ of diesel on a single, end energy user with a 10-kW PV installed system.

A single-end energy user rooftop PV system approach is financially viable and has significant potential to mitigate GHG emissions in its lifetime, while at the same time, it avoids the burning of fossil fuels such as oil, gasoline, etc. However, a community of end energy users based on rooftop PV systems, the potential and impact is much higher. For instance, a community of ten end energy users avoids the burning of 1,052,000 $\mathrm{L}$ of oil in the life time of the PV system. Every addition of rooftop PV system energy users adds surplus green energy to the fossil fuel-based grid while reducing GHG production due to avoiding the burning of 105,200 L of diesel. The trend is shifting to green energy sources such as rooftop PV systems, which will affect and change the dynamics of the power industry with its global major share of GHG emissions production.

\section{Stand-alone PV system analysis}

A stand-alone PV system uses a battery storage system to store surplus energy generated by the PV system and not utilized by the loads. In this section, a stand-alone PV system financial analysis is considered. The capability of $10-\mathrm{kW}$ PV system energy production remains the same. However, it is considered that load and battery storage consume all the generated potential, hence surplus energy is not wasted and the GHG mitigation potential of the PV system remains the same. However, the inclusion of a battery system in the PV system changes the financial perspectives of the project. In this study, a lithiumion battery is considered. A 5-kWh battery provides $1 \mathrm{~h}$ of backup to a $2.5-\mathrm{kW}$ load and has an average 7 years of life time as indicated by energy experts. The capital cost of the project raised to $9077 \$$ while feasibility study, engineering, and power system costs remained same and inverter and miscellaneous section share increased to $40.8 \%$. Moreover, operation and maintenance costs due 
to battery replacement after its 7-year life have increased to $710 \$$. Considering all the financial parameters defined in section 3, the 10-kW PV system payback (equity) calculated through RETScreen Expert is 9 years. Cumulative cash flows are shown in Fig 4.

\section{Discussion}

Green is a renewable but intermitted energy source. The PV system is used to mitigate the GHG emissions of the fossil fuel-based main grid. Therefore, the literature has carried out PV system investment, return, sensitivity, GHG, etc., analyses across the different regions of the globe, such as Ghana [32], UAE [33], Pakistan [3], Nigeria [7, 31], Bangladesh [27], Chile [28], Iran [29], etc. However, the focus of the literature is mainly on mega-scale PV systems, i.e., PV systems with an installed capacity of mega-watts [7, 27-29]. The minute role of the PV system on the rooftops of end energy users is underestimated [30]. Moreover, the selection of location for PV system installation is based on limited factors such as solar radiation [3], and the orientation angles, especially in the case of a fixed PV system, are not carefully selected, which highly limits the potential of PV system potential in terms of solar radiation intercepted hence, performance and output [30]. However, literature on mega-scale and rooftop PV system has utilized grid-tied PV system schemes to utilize the maximum potential of the intermittent nature of the PV system during its availability and surplus production compared to required demand $[30,32]$ while ignoring the battery role mainly due to financial issues in rooftop PV systems [34], since it increased the payback time by 4 years ( 5 years for gridtied systems and 9 years for stand-alone PV systems) for 2.5-kW load with $1 \mathrm{~h}$ backup.

Therefore, the proposed PV system study dealt with issues of literature by focusing on the minute scale but the prominent role of PV-equipped end energy users. Moreover, location is selected considering the two

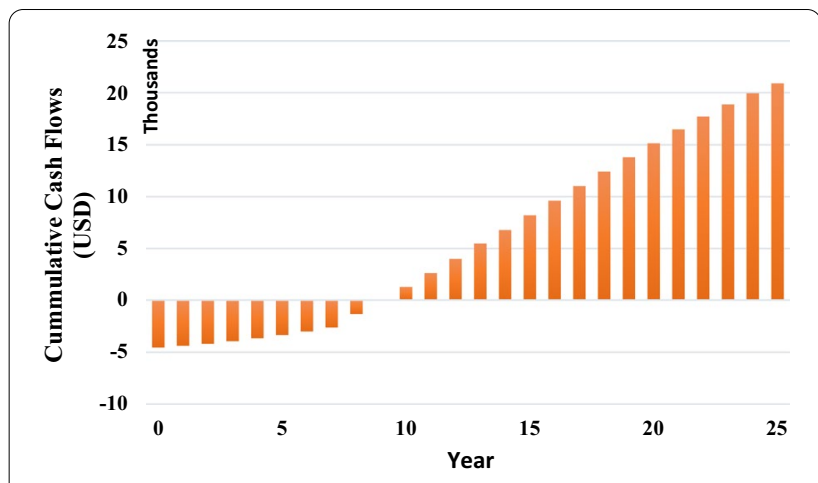

Fig. 4 Stand-alone PV system cash flows prominent factors, i.e., solar radiation and ambient temperature, which play a role in PV system performance and output $[3,23,30]$. The interception of solar radiation on the PV surface is further increased by carefully adjusting the orientation angles of PV system using Helioscope software. The role of a single end energy user in terms of its GHG mitigation potential was highlighted with financial analysis to attract the end energy user through its economics and good payback time by utilizing grid-tied PV systems. The approach followed by the study supports the green efforts and targets set in the Paris Climate Accord [9], Kyoto protocol [10], and European Union targets- 2020, 2030 and 2050 [1113 ] and respective governments, while supporting the power and energy industry through peak shaving and grid stabilization through green energy. However, this study requires experimental validation in the future to support the analysis, which requires financial support from organizations.

\section{Conclusion}

Electricity is required to meet industrial, commercial, and household energy demands, which is supplied by the fossil fuel-dominated main grid. The burning of fossil fuels releases gases like $\mathrm{CO}_{2}, \mathrm{NO}_{\mathrm{x}}$, water vapors, etc., that are responsible for global warming and climate change. Since energy has prime importance with environmental concerns, it has moved the world towards green renewable energy sources such as solar photovoltaic systems. However small an entity in the energy paradigm, end energy users have GHG emissions mitigation potential with their grid-tied rooftop PV systems. The 10-kW PV system meets his energy demands and trades surplus energy with the main grid. Moreover, a single end-user techno-economic analysis financially supports the end-user by recovering its $7337 \$$ investment through a 5 year payback time (equity) by producing 16,832 kWh of energy per annum after carefully adjusting fixed PV system orientation angles through Helioscope and RETScreen Expert software with geographical data retrieved from NASA Meteorological Data. A 10-kW PV system at end-user premises mitigates 8.3 tons of $\mathrm{CO}_{2}$ equivalent emissions per annum, which is equivalent to 1.9 acres of forest absorbing carbon or 2.9 tonnes of waste being recycled. Apart from environmentally friendly, this approach relieves end-user from high electricity pricing while shaving peak at grid by generating electricity.

Future work includes the practical justification of the study concept and with a detailed study of electric vehicle charging stations based on PV systems to mitigate GHG emissions in the transport sector as well. 


\section{Acknowledgements}

The authors acknowledge Mr. Musa Kazim Naeem, Solar Industry Expert, for providing us with the necessary data and guidance. We also acknowledge native English speaker Keith Imrie's professional English editing service.

\section{Authors' contributions}

JAS: conceptualization and approach. WA: literature, methodology, writing, results. MN: literature. MFU: results, formatting and MAPM: review and supervision. All authors read and approved the final manuscript.

\section{Funding}

We received no funding.

\section{Availability of data and materials}

NASA Meterological Data are provided by RETScreen Software. Tilt and azimuthal angle data are provided by Helioscope software.

\section{Declarations}

Ethics approval and consent to participate

Not applicable.

\section{Consent for publication}

We, authors, allow the publisher to publish our work.

\section{Competing interests}

The authors declare no competing interests.

\section{Author details}

${ }^{1}$ Secret Minds, Entrepreneurial Organization, Islamabad 44000, Pakistan. ${ }^{2} \mathrm{Fac}-$ ulty of Sociology, University of Wah, Wah 47040, Pakistan. ${ }^{3}$ School of Engineering, Deakin University, Geelong, VIC 3216, Australia. ${ }^{4}$ Faculty of Mechatronics Engineering Department, University of Wah, Wah 47040, Pakistan.

Received: 9 September 2020 Accepted: 2 September 2021 Published online: 17 September 2021

\section{References}

1. Rauf O, Wang S, Yuan P, Tan J (2015) An overview of energy status and development in Pakistan. Renew Sustain Energy Rev 48:892-931

2. Nazir MS, Mahdi AJ, Bilal M, Sohail HM, Ali N, Iqbal HM (2019) Environmental impact and pollution-related challenges of renewable wind energy paradigm - a review. Sci Total Environ 683:436-444

3. Khalid A, Junaidi H (2013) Study of economic viability of photovoltaic electric power for Quetta-Pakistan. Renewable Energy 50:253-258

4. National Transmission and Despatch Company Limited, Energy Resources Report 2017-2018. http://ntdc.gov.pk/energy. Accessed 29 July 2020.

5. Dudley, B. (2018). BP statistical review of world energy. BP Statistical Review, London, UK, accessed Aug, 6(2018), 00116

6. Farangi M, Soleimani EA, Zahedifar M, Amiri O, Poursafar J (2020) The environmental and economic analysis of grid-connected photovoltaic power systems with silicon solar panels, in accord with the new energy policy in Iran. Energy. https://doi.org/10.1016/j.energy.2020.117771

7. Njoku HO, Omeke OM (2020) Potentials and financial viability of solar photovoltaic power generation in Nigeria for greenhouse gas emissions mitigation. Clean Technol Environ Policy. https://doi.org/10.1007/ s10098-019-01797-8

8. Rehmani MH, Reisslein M, Rachedi A, Erol-Kantarci M, Radenkovic M (2018) Integrating renewable energy resources into the smart grid: recent developments in information and communication technologies. IEEE Trans Industr Inf 14(7):2814-2825

9. The Paris Agreement-main page n.d. http://unfccc.int/paris_agreement/ items/9485.php. Accessed 5 May 2020.

10. Kyoto Protocol n.d. http://unfccc.int/resource/docs/convkp/kpeng.pdf. Accessed 5 May 2020.

11. European Commission 2020 climate \& energy package https://ec.europa eu/clima/policies/strategies/2020_en. Accessed 5 May 2020.
12. European Commission 2030 climate \& energy framework https://ec. europa.eu/clima/policies/strategies/2030 en. Accessed 5 May 2020.

13. European Commission 2050 long-term strategy https://ec.europa.eu/ clima/policies/strategies/2050_en. Accessed 5 May 2020

14. Mirjat NH, Uqaili MA, Harijan K, Valasai GD, Shaikh F, Waris M (2017) A review of energy and power planning and policies of Pakistan. Renew Sustain Energy Rev 79:110-127

15. Kamran M, Mudassar M, Abid I, Fazal MR, Ahmed SR, Abid MI, Khalid R, Anjum SH (2019) Reconsidering the power structure of Pakistan. Int J Renew Energy Res. 9:480-492

16. Lin B, Raza MY (2019) Analysis of energy related CO2 emissions in Pakistan. J Clean Prod 219.981-993

17. Solangi $K H$, Islam MR, Saidur R, Rahim NA, Fayaz H (2011) A review on global solar energy policy. Renew Sustain Energy Rev 15(4):2149-2163

18. Ulfat I, Javed F, Abbasi FA, Kanwal F, Usman A, Jahangir M, Ahmed F (2012) Estimation of solar energy potential for Islamabad, Pakistan. Energy Procedia 18:1496-1500. https://doi.org/10.1016/j.egypro.2012.05.166

19. Raza W, Hammad S, Shams U, Maryam A, Mahmood S, Nadeem R (2015) Renewable energy resources current status and barriers in their adaptation for Pakistan. J Bioprocess Chem Eng 3(3):1-9

20. Aqeeq MA, Hyder SI, Shehzad F, Tahir MA (2018) On the competitiveness of grid-tied residential photovoltaic generation systems in Pakistan: Panacea or paradox? Energy Policy 119:704-722

21. Rehman SAU, Cai Y, Fazal R, Das Walasai G, Mirjat NH (2017) An integrated modeling approach for forecasting long-term energy demand in Pakistan. Energies 10(11):1868

22. Net-Metering Reference Guide For Electricity Consumer, Pakistan https://www.aedb.org/images/NetmeteringGuidlinesforConsumers.pdf. Accessed 27 Mar 2021.

23. Dubey S, Sarvaiya JN, Seshadri B (2013) Temperature dependent photovoltaic (PV) efficiency and its effect on PV production in the world-a review. Energy Procedia 33:311-321

24. Adaramola MS, Paul SS, Oyewola OM (2014) Assessment of decentralized hybrid PV solar-diesel power system for applications in Northern part of Nigeria. Energy Sustain Dev 19:72-82

25. Loughlin DH, Yelverton WH, Dodder RL, Miller CA (2013) Methodology for examining potential technology breakthroughs for mitigating $\mathrm{CO} 2$ and application to centralized solar photovoltaics. Clean Technol Environ Policy 15(1):9-20

26. RETScreen International (2005) RETScreen Software Online User Manual. CANMET Energy Technology Centre, Varennes, Quebec, Canada. http:// www.nrcan.gc.ca/energy/software-tools/7465. Accessed 28 Apr 2020.

27. Mondal MAH, Islam AS (2011) Potential and viability of grid-connected solar PV system in Bangladesh. Renew Energy 36(6):1869-1874

28. Bustos F, Toledo A, Contreras J, Fuentes A (2016) Sensitivity analysis of a photovoltaic solar plant in Chile. Renewable Energy 87:145-153

29. Bakhshi-Jafarabadi R, Sadeh J, Dehghan M (2020) Economic evaluation of commercial grid-connected photovoltaic systems in the Middle East based on experimental data: a case study in Iran. Sustain Energy Technol Assess 37:100581

30. Ahmed W, Sheikh JA, Kouzani AZ, Mahmud MA (2020) The role of single end-users and producers on GHG mitigation in Pakistan-a case study. Sustainability 12(20):8351

31. Owolabi AB, Nsafon BEK, Roh JW, Suh D, Huh JS (2019) Validating the techno-economic and environmental sustainability of solar PV technology in Nigeria using RETScreen Experts to assess its viability. Sustain Energy Technol Assess 36:100542

32. Asumadu-Sarkodie S, Owusu PA (2016) The potential and economic viability of solar photovoltaic power in Ghana. Energy Source Part A 38(5):709-716

33. Harder E, Gibson JM (2011) The costs and benefits of large-scale solar photovoltaic power production in Abu Dhabi, United Arab. Emirates Renew Energy 36(2):789-796

34. Kappner $K$, Letmathe $P$, Weidinger $P$ (2019) Optimisation of photovoltaic and battery systems from the prosumer-oriented total cost of ownership perspective. Energy Sustain Soc 9(1):1-24

35. Patnaik B, Swain SC, Rout UK (2019) Modelling and performance of solar PV panel with different parameters. International Conference on Application of Robotics in Industry using Advanced Mechanisms. Springer, Cham, pp 250-259 
36. Helioscope: advance Solar Design Software https://www. Helioscope. $\mathrm{com} /$. Accessed 1 May 2020.

37. Chung D, Davidson C, Fu R, Ardani K, Margolis R (2015) US photovoltaic prices and cost breakdowns. Q1 2015 benchmarks for residential, commercial, and utility-scale systems (No. NREL/TP-6A20-64746). National Renewable Energy Lab NREL, Golden

38. Yazdanie M, Rutherford PD (2010) Renewable energy in Pakistan: policy strengths, challenges \& the path forward. ETH Zurich 2:112-119

39. Electrical Power Transmission and Distribution Losses (\% of Output) Pakistan (IEA Statistics). Available at: https://data.worldbank.org/indic ator/EG.ELC.LOSS.ZS?locations=PK

40. Xu L, Wang Y, Solangi YA, Zameer H, Shah SAA (2019) Off-grid solar PV power generation system in Sindh, Pakistan: a techno-economic feasibility analysis. Processes 7(5):308
41. Irfan M, Zhao ZY, Ahmad M, Rehman A (2019) A techno-economic analysis of off-grid solar PV system: A case study for Punjab Province in Pakistan. Processes 7(10):708

42. Shah SAA, Valasai GD, Memon AA, Laghari AN, Jalbani NB, Strait JL (2018) Techno-economic analysis of solar PV electricity supply to rural areas of Baluchistan, Pakistan. Energies 11(7):1777

\section{Publisher's Note}

Springer Nature remains neutral with regard to jurisdictional claims in published maps and institutional affiliations.
Ready to submit your research? Choose BMC and benefit from:

- fast, convenient online submission

- thorough peer review by experienced researchers in your field

- rapid publication on acceptance

- support for research data, including large and complex data types

- gold Open Access which fosters wider collaboration and increased citations

- maximum visibility for your research: over $100 \mathrm{M}$ website views per year

At BMC, research is always in progress.

Learn more biomedcentral.com/submissions 